\title{
A Reagent for Covalently Attaching Biotin to Proteins via a Cleavable Connector Arm'
}

\author{
CATHARINE A. MOUTON, DENNIS PANG, C. V. NATRAJ, \\ AND JULES A. SHAFER ${ }^{3}$ \\ Department of Biological Chemistry, University of Michigan Medical School, \\ Box 034, Ann Arbor, Michigan 48109
}

Received April 5, 1982, and in revised form May 11, 1982

The preparation of a reagent which can be used to attach biotin to proteins via a cleavable connector arm is described. The reagent, 3-(4- $(N$-biotinoyl-6-aminocaproyloxy)phenyl)propionic acid $N$-hydroxysuccinimide ester (BPE), can acylate amino groups of proteins and other compounds via reaction of the $N$-hydroxysuccinimide ester function. Compounds which have been covalently labeled with BPE can be selectively retrieved (at physiological $\mathrm{pH}$ values) from complex mixtures by adsorbing the target compounds on immobilized avidin. These compounds can be released from the avidin by cleavage of the phenyl ester linkage of the connector arm under conditions which don't denature proteins. Insulin was labeled with BPE. The binding of the labeled insulin to immobilized avidin, and its subsequent release by treatment at room temperature with $1 \mathrm{M}$ hydroxylamine at $\mathrm{pH} 7$ was demonstrated.

The highly specific and very strong binding of biotin to avidin $\left(K_{D} \sim 10^{-15} \mathrm{M}\right.$; (7)) could provide us with a basis for the design of elegant protocols for the retrieval of compounds from cells and physiological fluids even when the compounds targeted for retrieval are present at very low concentrations. For example, a polypeptide hormone that had been covalently labeled with biotin could be incubated with cells and later retrieved by adsorption on immobilized avidin for studies of hormone catabolism and for isolation of hormonereceptor complexes. Unfortunately, the direct application of this approach is usually precluded by the very low rate constant for the dissociation of biotin from

\footnotetext{
${ }^{1}$ Financial support for this work from National Institutes of Health Grant AM 27659 is gratefully acknowledged.

${ }^{2}$ Present address: Unilever Research, Colworth Laboratory, Colworth House, Shornbrook Bedford MK44 ILQ, England.

"To whom inquiries should be addressed.
}

avidin $\left(t_{1 / 2} \sim 200\right.$ days; $\left.(7)\right)$, and the fact that all of the methods which are known to increase the rate of decomposition of the avidin:biotin complex lead to irreversible protein denaturation. This difficulty has been overcome to some extent by the use of 2 -iminobiotin $(8,10)$. Unlike biotin, 2 -iminobiotin interacts with avidin very poorly at low $\mathrm{pH}$ values. Thus, proteins labeled with 2 -iminobiotin can be eluted from immobilized avidin at $\mathrm{pH}$ 4. There are two limitations associated with the use of 2-iminobiotin, however. One is that the $\mathrm{pH}$ must be above 9.5 for immobilized avidin to exhibit significant adsorption of 2iminobiotin-labeled proteins from dilute solutions (10). The other is that avidin binds 2-iminobiotin much less tightly than biotin. For example, the relative affinity of biotin and 2-iminobiotin for avidin is $2.8 \times 10^{7}$ at $\mathrm{pH} 9.5$ and $3.5 \times 10^{4}$ at $\mathrm{pH}$ values well above 12 where 2-iminobiotin $\left(\mathrm{p} K_{a}\right.$ 11.9) exists primarily in its basic form. These considerations suggest that a biotin label might be more useful than 
a 2-iminobiotin label for specific retrieval of proteins and macromolecular complexes of proteins which are unstable in alkaline solution or are present at very low concentrations (or both). In this work we describe the preparation of a biotin derivative (BPE) ${ }^{4}$ which can be used to link bio-

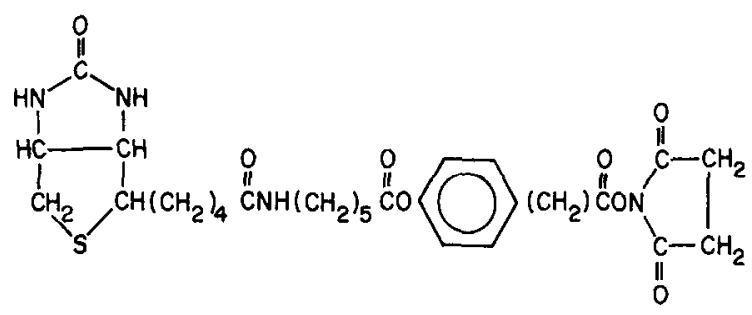

BPE

tin to polypeptides and other compounds via a cleavable connector arm. After the biotinoylated compound has been adsorbed on immobilized avidin under physiological conditions, it can be selectively released from the avidin by breaking the phenyl ester linkage in the connector arm. The cleavable phenyl ester linkage contained in BPE has an advantage over other cleavable linkages commonly used in crosslinking agents, in that it can be broken under mild conditions which do not result in reduction of disulfide bonds or oxidation of glycosyl residues.

\section{MATERIALS AND METHODS}

$\mathrm{N}$-Hydroxysuccinimide (NHS) obtained from Aldrich Chemical Company was recrystallized from ethyl acetate. Dimethyl sulfoxide $\left(\mathrm{Me}_{2} \mathrm{SO}\right)$ was dried over a molecular sieve and trifluoroacetic acid (Aldrich Chemical Co.) was distilled. Triethylamine, dimethylformamide (DMF), isopropanol, and dioxane were distilled from phthalic anhydride, $\mathrm{P}_{2} \mathrm{O}_{5}, \mathrm{Ca}_{2} \mathrm{SO}_{4}$, and $\mathrm{LiAlH}_{4}$, respectively.

Benzyl 3-(4-hydroxyphenyl)propionate (I). 3-(4-Hydroxyphenyl)propionic acid (HPPA), $50 \mathrm{~g}(0.3 \mathrm{~mol})$ as obtained from Aldrich Chemical Company, was converted to the monopotassium salt by dissolving it in $300 \mathrm{ml}$ of $1 \mathrm{~N} \mathrm{KOH}$, and removing the water under reduced pressure. The monopotassium salt of HPPA was dissolved in $400 \mathrm{ml}$ of warm $95 \%$ ethanol in a round-bottom flask equipped with a reflux condenser. The solution was heated to reflux, and benzyl bromide $(32.5 \mathrm{ml}, 0.273 \mathrm{~mol})$ in $100 \mathrm{ml}$ of ethanol was added over $1 \mathrm{~h}$ with stirring. The reaction mixture was heated under reflux for another $1.5 \mathrm{~h}$, whereupon it was cooled, and the ethanol removed under reduced pressure. The resulting oil was suspended in 1.5 liters of $\mathrm{H}_{2} \mathrm{O}$, neutralized to $\mathrm{pH} 7$ with $\mathrm{NaHCO}_{3}$, and stirred for $0.5 \mathrm{~h}$. The aqueous suspension was then extracted three times with ether, and the combined ether extract, was back-extracted with $0.02 \mathrm{~N}$ sodium phosphate buffer ( $\mathrm{pH} 7$ ). After the ether extract was dried over sodium sulfate, the ether was removed under reduced pressure, and the resulting oil was distilled under reduced pressure. The fraction which boiled at $170-174^{\circ} \mathrm{C}, 0.03 \mathrm{~mm} \mathrm{Hg}$, was collected to yield 46.8 $\mathrm{g}(68 \%)$ of the desired product, an oil $(d=1.179)$ NMR $\left(60 \mathrm{MHz} \mathrm{CDCl}_{3}+1 \%\right.$ TMS) $\delta 7.28(5 \mathrm{H}, \mathrm{s}, \mathrm{ArH}), \delta 6.92$ $(4 \mathrm{H}, \mathrm{m}, \mathrm{ArH}), \delta 5.09\left(2 \mathrm{H}, \mathrm{s}, \mathrm{ArCH}_{2} \mathrm{O}\right), \delta 2.72(4 \mathrm{H}, \mathrm{m}$, $\mathrm{CH}_{2}$ ). The product exhibited a change in molar absorptivity accompanying neutralization (with $\mathrm{KOH}$ ) of the phenolic hydroxyl group which was within $3 \%$ of that seen for HPPA $\left(\Delta_{2} 2952540 \mathrm{~cm}^{-1} \mathrm{M}^{-1}\right.$ in $20 \%$ ethanol-water).

$N$-Benzyloxycarbonyl-6-aminocaproic acid (II). Benzyl chloroformate $(48 \mathrm{ml}, 0.34 \mathrm{~mol})$ was added slowly (over $1 \mathrm{~h}$ ) to a vigorously stirred solution of 6-aminocaproic acid $(40 \mathrm{~g}, 0.31 \mathrm{~mol})$ in $38 \mathrm{ml}$ of $4 \mathrm{~N}$ $\mathrm{NaOH}$ which was cooled in an ice bath, and maintained at $\mathrm{pH} 9.5-10.5$ by addition of $4 \mathrm{~N} \mathrm{NaOH}$. After addition of the benzyl chloroformate, the solution was stirred for another $5 \mathrm{~min}$, extracted three times

${ }^{4}$ Abbreviations used: B-insulin, the derivatives of insulin produced upon modification of insulin and tracer amounts of [ $\left.{ }^{125} I\right]$ insulin with excess biotin $N$ hydroxysuccinimide ester; BPE, 3-(4-(biotinoyl-6aminocaproyloxy)phenyl)propionic acid $N$-hydroxysuccinimide ester; BPE-insulin, the derivatives of insulin produced upon modification of insulin and tracer amounts of $\left.{ }^{125} \mathrm{I}\right]$ insulin with excess BPE; BSA, bovine serum albumin; DMF, dimethylformamide; HPPA, 3-(4-hydroxyphenyl)propionic acid; NHS, $N$ hydroxysuccinimide; NHS-CM-Sepharose, a derivative of CM-Sepharose wherein the Sepharose-linked carboxylic acid groups have been converted to $N$-hydroxysuccinimide esters; avidin-Sepharose, an immobilized avidin derivative obtained by reacting avidin with NHS-CM-Sepharose; Me, methyl. 
with ether, and acidified to $\mathrm{pH} 1$ with concentrated $\mathrm{HCl}$. The resulting precipitate was extracted into ethyl acetate. After drying the extract over $\mathrm{Na}_{2} \mathrm{SO}_{4}$, the ethyl acetate was removed under reduced pressure. The solid residue was purified by three recrystallizations from ether:petroleum ether to yield $\mathbf{5 3 . 9}$ $\mathrm{g}(68 \%)$ of the desired product, $\mathrm{mp} 55^{\circ} \mathrm{C}$ (lit. $54-55^{\circ} \mathrm{C}$ ) (11) ir (KBr) amide $1732 \mathrm{~cm}^{-1}$, NMR (60 $\mathrm{MHz}, \mathrm{CDCl}_{3}$ $+1 \%$ TMS $) \delta 7.36(5 \mathrm{H}, \mathrm{s}, \mathrm{ArH}), \delta 5.08\left(2 \mathrm{H}, \mathrm{s}, \mathrm{ArCH}_{2}\right)$, $\delta 3.15, \delta 2.30, \delta 1.42\left(10 \mathrm{H}, \mathrm{m}, \mathrm{CH}_{2}\right)$.

Benzyl 3-(4-(N-benzyloxycarbonyl-6-aminocaproyloxy)phenyl)propionate (III). II (12 g, $45 \mathrm{mmol})$, I (12 $\mathrm{ml}, 54 \mathrm{mmol})$, and $\mathrm{POCl}_{\mathrm{a}}(2 \mathrm{ml}, 22 \mathrm{mmol})$ were mixed in a round-bottom flask equipped with a reflux condenser. The reaction mixture was heated in an oil bath at $100^{\circ} \mathrm{C}$ for $1.25 \mathrm{~h}$, then cooled to room temperature, and extracted with ether by stirring the solution vigorously with three $300-\mathrm{ml}$ portions of ether. The combined ether extract was back-extracted three times with $0.02 \mathrm{~N}$ sodium phosphate buffer ( $\mathrm{pH} \mathrm{7)}$. Ether was removed from the ether extract under reduced pressure. The residue was taken up in benzene and the benzene removed under reduced pressure. This process was repeated once so as to remove traces of water. The resulting residue, $12 \mathrm{~g}$ of crude III, was used without further purification. The phenyl ester content of crude III was determined as described below and was $59 \%$ of that expected for pure III.

3-(4-(6-Aminocaproyloxy)phenyl)propionic acid hydrobromide (IV). Crude III ( $2.49 \mathrm{~g}$ containing 2.92 mmol phenyl ester) and anisole ( $1 \mathrm{ml}, 9.2 \mathrm{mmol})$ were mixed with $9 \mathrm{ml}$ of trifluoroacetic acid, and $\mathrm{HBr}(\mathrm{g})$ was bubbled through the reaction mixture. After 1.75 $h$, (which was found to be the optimum reaction time), the reaction mixture was poured with stirring into $300 \mathrm{ml}$ of ether. The optimum reaction time for removal of the benzyl and benzyloxycarbonyl groups was indicated by the formation of a precipitate approximately $5 \mathrm{~min}$ after $50 \mu \mathrm{l}$ of the reaction mixture had been added to $1 \mathrm{ml}$ of ether. Extended reaction times resulted in decomposition of the desired reaction product. After the reaction mixture had becn stirred with the ether for $20 \mathrm{~min}$, the resulting solid was collected, dissolved in ethanol, and precipitated with ether repeatedly to yield $0.46 \mathrm{~g}(44 \%)$ of IV $\mathrm{mp}$ $160-161^{\circ} \mathrm{C}$. The phenyl ester content (see below) of IV was $100 \%$ of that expected for pure IV, NMR (60 $\mathrm{Hz}, \mathrm{DMSO}-d_{6}+1 \%$ TMS) $\delta 1.52\left(6 \mathrm{H}, \mathrm{m}, \mathrm{CH}_{2}\right), \delta 2.70$ $\left(8 \mathrm{H}, \mathrm{m}, \mathrm{CH}_{2}\right), \delta 7.20(4 \mathrm{H}, \mathrm{m}, \mathrm{ArH}), \delta 7.98(3 \mathrm{H}$, $\mathrm{m}, \mathrm{NH}_{3}^{+}$).

Biotin N-hydroxysuccinimide ester (V). This compound was synthesized using a procedure similar to that of May et al. (9). A solution of biotin $(4.01 \mathrm{~g}, 16.4$ mmol) and NHS (2.075 g, $18.0 \mathrm{mmol})$ in $70 \mathrm{ml}$ of $\mathrm{Me}_{2} \mathrm{SO}$ was dried over molecular sieve ( $4 \AA$ ) for 1.25 h. The molecular sieve was removed, washed with 5 $\mathrm{ml}$ of dry $\mathrm{Me}_{2} \mathrm{SO}$, and the wash was combincd with the solution of biotin and NHS. $N, N^{\prime}$-Dicyclohexylcarbodiimide $(3.4 \mathrm{~g}, 16.5 \mathrm{mmol})$ in $40 \mathrm{ml}$ of $\mathrm{Me}_{2} \mathrm{SO}$ was added dropwise over $30 \mathrm{~min}$ to a stirred solution of the biotin and NHS. After $16 \mathrm{~h}$, the $N, N^{\prime}$-dicyclohexylurea which had precipitated was removed by filtration. $\mathrm{Me}_{2} \mathrm{SO}$ was removed from the filtrate at $70^{\circ} \mathrm{C}$ under reduced pressure, and the resulting product purified by two successive precipitations from $1 \%$ acetic acid in DMF with ether. It was obtained in a $60 \%$ yield $(3.35 \mathrm{~g})$, $\mathrm{mp} 208-210^{\circ} \mathrm{C}$, (lit. 208$\left.210^{\circ} \mathrm{C}\right)(9)$.

g - (4 - (N - Biotinoyl - 6 - aminocaproyloxy)phenyl)propionic acid (VI). A solution composed of $8.6 \mathrm{mmol}(1.2 \mathrm{ml})$ triethylamine in $20 \mathrm{ml}$ of $\mathrm{Me}_{2} \mathrm{SO}$ was added (during $5 \mathrm{~min}$ ) to a stirred solution of $\mathrm{V}$ $(1 \mathrm{~g}, 2.93 \mathrm{mmol})$ and IV $(1.14 \mathrm{~g}, 3.19 \mathrm{mmol})$ in $50 \mathrm{ml}$ of $\mathrm{Me}_{2} \mathrm{SO}$. The reaction mixture was stirred for an additional $13 \mathrm{~min}$, whereupon it was poured onto 600 g crushed ice which had been acidified with $4 \mathrm{ml}$ of concentrated $\mathrm{HCl}$. The resulting precipitate was rinsed with $0.01 \mathrm{~N} \mathrm{HCl}$, ice water, and $20 \mathrm{ml}$ of $1 \%$ acetic acid in acetonitrile; and then dried under reduced pressure at room temperature to yield $1.13 \mathrm{~g}$ $(76 \%)$ of VI $\mathrm{mp} 199-200^{\circ} \mathrm{C}$. The biotin content and phenyl ester content (see below) of this material were 99 and $97 \%$, respectively, of that expected for the pure compound.

3 - (4 - (N-Biotinoyl - 6 - aminocaproyloxy)phenyl)propionic acid $N$-hydroxysuccinimide ester (VII). This compound was prepared from VI in a manner similar to that used to prepare the $N$-hydroxysuccinimide ester of biotin. The product $(\mathrm{mp}$ $177-179^{\circ} \mathrm{C}$ ) was obtained in $62 \%$ yield $(732 \mathrm{mg}$ ) from $1 \mathrm{~g}(1.97 \mathrm{mmol})$ of VI. It exhibited phenyl ester, biotin, and $N$-hydroxysuccinimide ester contents (see below) which were 101,99 , and $100 \%$ of that expected for the pure VII. The product also chromatographed as a single component on HPLC on a 250 by 4.6 (i.d.)mm Whatman Partisil-10 ODS C-18 column using $1 \%$ acetic acid-2\% DMF-97\% acetonitrile (v/v/v) as eluent. Initial preparations of VII (prepared from impure VI) yielded a crude product from which pure VII could be obtained by this HPLC procedure.

NHS-CM-Sepharose. CM-Sepharose CL-6B (20 ml) obtained from Pharmacia was washed on a sintered glass funnel with $350 \mathrm{ml}$ of $0.1 \mathrm{~N} \mathrm{HCl}, 250 \mathrm{ml}$ of water, and then with $60 \mathrm{ml}$ of dioxane. The washed gel was activated with NHS according to a procedure similar to that of Cuatrecasas and Parikh (3). For activation, the washed gel was stirred with NHS $(691 \mathrm{mg}, 6$ mmol) and $N, N^{\prime}$-dicyclohexylcarbodiimide $(1.24 \mathrm{~g}, 6$ $\mathrm{mmol}$ ) in $40 \mathrm{ml}$ of dioxane for $70 \mathrm{~min}$. After removal of the liquid phase, the gel was washed with $150 \mathrm{ml}$ of dioxane, $200 \mathrm{ml}$ methanol (to remove precipitated $N, N^{\prime}$-dicyclohexylurea), and $100 \mathrm{ml}$ dioxane. The resulting NHS-CM-Sepharose was stored under dioxane.

Avidin Sepharose. NHS-CM-Sepharose $(150 \mu \mathrm{l})$ was 
washed with ice-cold $0.1 \mathrm{M}$ phosphate buffer (pH 7.0) and added to $8.16 \mathrm{mg}$ (124 nmol) of avidin (from Sigma) in $0.8 \mathrm{ml}$ of ice-cold $0.1 \mathrm{M}$ phosphate buffer (pH 7.0). The resulting suspension was stirred for 3 $h$ at room temperature. The gel was then washed four times with $1.0 \mathrm{ml}$ of $0.1 \mathrm{M}$ phosphate buffer ( $\mathrm{pH} \mathrm{7.0)}$ and shaken with $1 \mathrm{ml}$ of $1.0 \mathrm{M}$ ethanolamine in 1.0 M phosphate ( $\mathrm{pH} 7.0$ ) to decompose unreacted NHS ester. The resulting gel was washed six times with $1.0 \mathrm{ml}$ of $0.1 \mathrm{M}$ phosphate buffer ( $\mathrm{pH} 7.0$ ) and the avidin-linked gel was diluted 1:100 with gel that had been activated with NHS and then inactivated with ethanolamine without addition of avidin. The resulting gel mixture, avidin Sepharose, was suspended in sufficient $0.1 \mathrm{M}$ phosphate buffer ( $\mathrm{pH} \mathrm{7.0)}$ to produce a suspension that contained $100 \mu \mathrm{l}$ of $\mathrm{gel} / \mathrm{ml}$. Before use in studies of the binding of insulin to the gel, avidin Sepharose $(100 \mu \mathrm{l})$ was resuspended in 1.0 $\mathrm{ml}$ of $1.0 \mathrm{mg} / \mathrm{ml}$ bovine serum albumin (BSA) in 0.1 M phosphate buffer ( $\mathrm{pH}$ 7.0) to minimize nonspecific binding of insulin.

$\left[{ }^{125}\right.$ IInsulin Insulin (porcine, from Elanco) was iodinated with carrier free $\mathrm{Na}^{125} \mathrm{I}$ from Amersham by a modification of the method of Freychet et al (4). Insulin $(100 \mu \mathrm{g}, 17.4 \mathrm{nmol})$ in $0.12 \mathrm{ml}$ of $0.05 \mathrm{M}$ phosphate buffer ( $\mathrm{pH} 7.4$ ) was mixed with $2 \mathrm{mCi} \mathrm{Na}{ }^{125} \mathrm{I}$ $(0.91 \mathrm{nmol}$ in $3.7 \mu \mathrm{l})$ and $10 \mu \mathrm{l}$ of $0.35 \mathrm{mM}$ chloramine$\mathrm{T}$ in $0.05 \mathrm{M}$ phosphate buffer ( $\mathrm{pH} 7.4$ ). After $5 \mathrm{~min}$ the reaction was quenched by addition of $5 \mu \mathrm{l}$ of 0.70 mM sodium metabisulfite. The iodide and insulin were separated by gel exclusion chromatography on a 17 $\times 0.7$ (i.d.)-cm column of Sephadex G-25 Medium, which was eluted with $0.05 \mathrm{M}$ sodium phosphate buffer ( $\mathrm{pH} 7.4$ ).

[ ${ }^{125} \mathrm{I}$ Insulin derivative of $V I I(B P E$-insulin). Insulin ( $1 \mathrm{mg}, 0.17 \mu \mathrm{mol}$ ) in $2.0 \mathrm{ml}$ of a solution containing $30 \%$ acetonitrile-70\% $0.2 \mathrm{M}$ sodium phosphate buffer (pH 7.0) was stirred with a tracer amount $\left(1.75 \times 10^{7}\right.$ cpm) of [ [ ${ }^{125}$ ] $i n s u l i n$ in $50 \mu$ l of $0.05 \mathrm{M}$ phosphate buffer (pH 7.4) and $1 \mathrm{mg}(1.7 \mu \mathrm{mol})$ VII. After $5.5 \mathrm{~h}$ at room temperature, the reaction was quenched by addition of $20 \mu \mathrm{l} 1 \mathrm{M}$ glycine. The volume of the reaction $\mathrm{mix}$ ture was reduced to less than $1 \mathrm{ml}$ under a stream of air. The precipitate which formed was removed by centrifugation and dissolved in $1 \mathrm{ml} 0.02 \mathrm{M}$ sodium phosphate buffer ( $\mathrm{pH}$ 7.0). The resulting solution was subjected to gel exclusion chromatography on a 39 $\times 1$ (i.d.)-cm column of Sephadex G-25 medium and the insulin-containing fraction which appeared in the void volume was collected.

[ ${ }^{125}$ IIInsulin derivative of $V$ (B-insulin). This was prepared by a procedure similar to the one used to prepare BPE-insulin except that material which precipitated during evaporation was not separated. Instead, any precipitated material was dissolved by addition of sufficient $0.02 \mathrm{M}$ sodium phosphate buffer (pH 7.0) to obtain a final volume of $2 \mathrm{ml}$.
The phenyl ester content of compounds. This was determined from the time-dependent increase of absorbance at $298 \mathrm{~nm}$ due the release of the phenoxide ion which accompanies solvolysis of the phenyl ester in basic ethanol. In a typical assay, $75 \mu 1$ of a $10 \mathrm{mM}$ (by weight) solution of ester in ethanol or DMF was added to $3 \mathrm{ml}$ of ethanol which contained $5 \%$ by volume of a solution composed of $25 \%$ tetrabutylammonium hydroxide in methanol. The absorbance (298 $\mathrm{nm}$ ) of the solution was monitored continuously from the time of addition of the ester. The approach of the absorbance $(A)$ to its final value $\left(A_{f}\right)$ was first order, and linear plots of $\ln \left(A-A_{\mathrm{f}}\right)$ vs time were extrapolated to the time of mixing to obtain the initial absorbance $\left(A_{0}\right)$ of the solution. (It should be noted that the contribution of the phenyl ester chromophore to $A_{0}$ is negligible at $298 \mathrm{~nm}$ ). The concentration of phenyl ester [PE] in the cuvette was calculated from the relationship

$$
[\mathrm{PE}]=\left(A_{\mathrm{f}}-A_{0} / 2540,\right.
$$

where $2540 \mathrm{~cm}^{-1} \mathrm{M}^{-1}$ is the molar absorptivity of the phenoxide ion of HPPA. The standard deviation for this analysis was less than $3 \%$.

The biotin content of compounds. This was determined by a modification of the dye displacement method of Green (5). In a typical analysis, a $10 \mathrm{mM}$ solution of the biotin-containing compound in DMF was diluted to $5 \mu \mathrm{M}$ with $0.05 \mathrm{M}$ sodium phosphate, pH 6.5. A sample $(0.82 \mathrm{ml})$ of this solution and 0.18 ml of a solution containing $1.0 \mathrm{mg} / \mathrm{ml}$ avidin and 0.17 mM 2-(4-hydroxyazobenzene)benzoic acid in water were mixed to yield a final volume of $1 \mathrm{ml}$. The absorbance of this solution (at $500 \mathrm{~nm}$ ) was determined and related to the biotin content of the sample using the linear dependence of the absorbance on the biotin content observed for samples containing known amounts of biotin. The standard deviation for this analysis was less than $3 \%$.

The N-Hydroxysuccinimide ester content of VII. This was determined from measurements of the absorbance change $\left(\epsilon_{262}=9038 \mathrm{~cm}^{-1} \mathrm{M}^{-1}\right)$ which accompanied the release of NHS anion by imidazole. The absorbance (at $262 \mathrm{~nm}$ ) of solutions composed of 50 $\mu l$ of $10.2 \mathrm{mM}(6.17 \mathrm{mg} / \mathrm{ml})$ VII in DMF and $3 \mathrm{ml}$ of solutions containing: $70 \%$ by volume $0.3 \mathrm{M}$ sodium phosphate ( $\mathrm{pH}=7.1$ ), $30 \% \mathrm{Me}_{2} \mathrm{SO}$, and either $0.35 \mathrm{M}$ imidazole or no imidazole. The concentration of $\mathrm{N}$ hydroxysuccinimide ([NHS]) released was calculated from the equation

$$
[\mathrm{NHS}]=\left(A_{1}-A_{0}\right) / 9038,
$$

where $9038 \mathrm{~cm}^{-1} \mathrm{M}^{-1}$ is the molar absorptivity of NHS under the assay conditions, $A_{1}$ is the observed absorbance in the presence of $0.35 \mathrm{M}$ imidazole and $A_{0}$ is the observed initial absorbance of VII in the ab- 
sence of imidazole. The standard deviation for this analysis was less than $3 \%$.

General operations used with avidin Sepharose. Gels were treated with solutions at room temperature for the indicated times by shaking the mixtures on a Burrell wrist-action shaker or by stirring them on a magnetic stirrer. Both mixing procedures gave similar results. The reaction vessel was a $75 \times 12$ (o.d.)-mm glass test tube, which could be used as a sample container in the gamma counter (Searle Analytic Inc., Model 1190) for determinations of radioactive material in the gel phase. Gels were washed by treating them for $1 \mathrm{~min}$ with the specified wash solution. Solutions were separated from gels by centrifugation on an International Clinical desk top centrifuge. Prior to determination of their radioactivity aliquots of the supernatant solutions were subjected to a second centrifugation in a Beckman microfuge to ensure removal of trace amounts of gel.

Reaction of insulin derivatives with avidin Sepharase. Avidin Sepharose $(0.1 \mathrm{ml})$ was suspended in $\mathbf{0 . 5}$ $\mathrm{ml}$ of $0.1 \mathrm{M}$ sodium phosphate buffer, $0.1 \% \mathrm{BSA}$ ( $\mathrm{pH}$ 7.0) and treated for $4 \mathrm{~h}$ with the indicated amounts of BPE-insulin or B-insulin. The unbound insulin derivative was removed by centrifugation and the gel was washed three times with $1 \mathrm{ml}$ of $0.1 \mathrm{M}$ phosphate buffer, $1 \mathrm{mg} / \mathrm{ml} \mathrm{BSA}(\mathrm{pH} 7.0)$ and once by treating the gel for $40 \mathrm{~min}$ with $1 \mathrm{ml}$ of a buffer consisting of $0.1 \mathrm{M}$ phosphate, $1 \mathrm{M} \mathrm{NaCl}, 1 \mathrm{mg} / \mathrm{ml} \mathrm{BSA}$ ( $\mathrm{pH}$ 7.0). The radioactivity of the washes was monitored as well as the radioactivity of the washed gel. The last wash contained less than $2 \%$ of the radioactivity of that which was present in the washed gel.

Cleavage of phenyl ester linkages and release of gelbound insulin. This was accomplished by treating 0.1 $\mathrm{ml}$ gel for $40 \mathrm{~min}$ with $1 \mathrm{ml}$ of $1.0 \mathrm{M} \mathrm{NH} \mathrm{NH}_{2} \mathrm{OH}, 1 \mathrm{mg}$ / ml BSA (pH 7.0). The hydroxylamine solution was prepared by addition of $\mathrm{BSA}$ to $\mathrm{NH}_{2} \mathrm{OH}: \mathrm{HCl}$ which had been neutralized with $\mathrm{NaOH}$ to $\mathrm{pH} 7.0$, and ad-

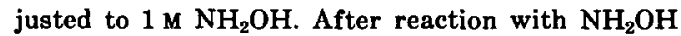
the gel was washed three times with $1 \mathrm{ml}$ of $0.1 \mathrm{M}$ phosphate buffer, $1 \mathrm{mg} / \mathrm{ml}$ BSA ( $\mathrm{pH} 7.0$ ). The release of radioactive insulin derivative from the gel was monitored by determination of the radioactivity in the gel and liquid phases.

The biotin binding capacity of avidin Sepharose. This was determined by treating a 1.0-ml aliquot of avidin Sepharose suspension for $1 \mathrm{~h}$ with $50 \mu \mathrm{l}$ of a solution containing a known concentration of biotin in water. The amount of biotin which bound to the gel was determined from the difference between the amount of biotin added and the amount of unbound biotin in the supernatant solution obtained after removal of the gel by centrifugation. The amount of biotin in the supernatant solution was determined in a manner similar to that described for the determination of the biotin content of organic compounds.
Biotin standards in the same buffer as the gel supernatant solution were used to calibrate the assay.

\section{RESULTS AND DISCUSSION}

Reaction of BPE with insulin resulted in covalent attachment of biotin to insulin as evidenced by the behavior of the resultant BPE-insulin toward avidin Sepharose (see below). The reaction of BPE with insulin should be analogous to that reported for the reaction of biotin $N$-hydroxysuccinimide ester (V) with insulin wherein $N$ hydroxysuccinimide is displaced from $\mathrm{V}$ by the amino groups of insulin with concomitant formation of amide bonds (9). The biotin in the insulin derivative of $\mathrm{V}$ (B-insulin), however, is linked to the insulin via a noncleavable linkage, whereas in BPE-insulin the biotin is attached to the insulin via a cleavable connector arm. Since there are three amino groups in insulin, seven derivatives can result from the reaction of insulin with BPE or $\mathrm{V}^{5}$ In the procedure used in this work to label insulin with BPE or $\mathrm{V}$, a greater than ninefold molar excess of BPE or $V$ was reacted with insulin for $5.5 \mathrm{~h}$ to ensure that essentially all of the insulin molecules would be covalently linked to at least one biotin group. ${ }^{6}$ Furthermore, the insulin was reacted in the presence of tracer amounts of $\left[{ }^{125} \mathrm{I}\right] \mathrm{insulin}$ to facilitate quantification of the binding of the resulting BPE-insulin or B-insulin to immobilized avidin (avidin-Sepharose). The titrations

\footnotetext{
${ }^{5}$ The seven insulin derivatives of $\mathrm{V}$ and BPE have been separated by HPLC. The preparation and physiological properties of these derivatives will be described elsewhere.

${ }^{6}$ The derivitized insulins used here are primarily trisubstituted with biotin. To obtain the other BPEinsulin derivatives, a mixture of the seven derivatives was prepared by reaction of a ninefold molar excess of BPE with $2 \mathrm{mg} / \mathrm{ml}$ insulin in a solution composed of equal volumes of acetonitrile and $0.2 \mathrm{M}$ sodium phosphate buffer ( $\mathrm{pH} 6.6$ before mixing). After 45 min the reaction mixture was quenched by addition of 0.1 volume of $2 \mathrm{M}$ phosphoric acid. The seven BPEinsulin derivatives were isolated from each other and unreacted insulin by HPLC on a C-8 column using an acetonitrile-sodium phosphate ( $\mathrm{pH}$ 3.1) gradient as eluent.
} 


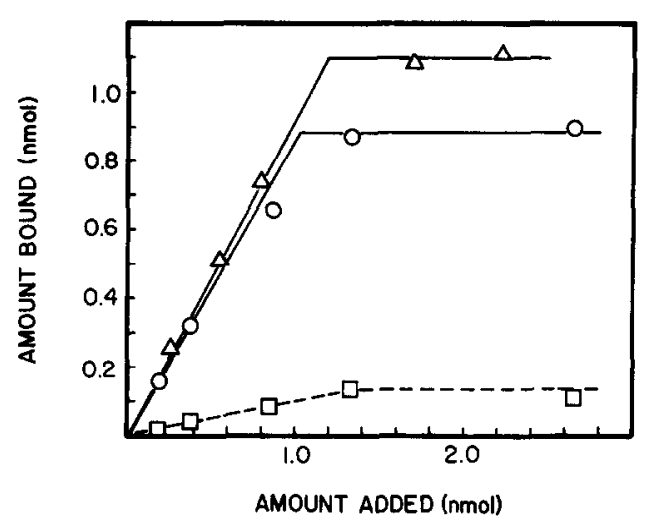

FIG. 1. Titration of avidin Sepharose with BPEinsulin and B-insulin. The indicated amounts of BPEinsulin $(O)$ and B-insulin $(\triangle)$ were stirred for $4 \mathrm{~h}$ with $0.1 \mathrm{ml}$ of avidin Sepharose in $0.1 \mathrm{M}$ sodium phosphate buffer $(\mathrm{pH} 7)$ in a total volume of $1.03-1.3 \mathrm{ml}$. The squares indicate the amount of BPE-insulin remaining bound after treatment of the bound insulin (O) with $1 \mathrm{M}$ hydroxylamine ( $\mathrm{pH} 7$ ) for $40 \mathrm{~min}$ at room temperature. Treatment of bound B-insulin $(\Delta)$ with hydroxylamine resulted in no change $(<2 \%)$ in the amount of B-insulin bound to the avidin Sepharose.

of avidin Sepharose depicted in Fig. 1 yield binding capacities of $11 \mathrm{nmol}$ B-insulin and $8.9 \mathrm{nmmol} \mathrm{BPE-insulin} \mathrm{per} \mathrm{milliliter}$ of avidin Sepharose. Separate determinations of the capacity of the gel to bind free biotin indicated that the avidin Sepharose could bind $31 \mathrm{nmol}$ of biotin per milliliter of gel. The approximately threefold lower binding capacity observed with BPE-insulin and B-insulin may well reflect, in part, the ability of the polyvalent biotinoylated insulin derivatives to fill more than one biotin binding site. Limited access of the insulin derivatives to the biotin binding sites of the immobilized avidin could also account for the lower capacity of the gel to bind insulin. It should be noted that the avidin Sepharose used in this work resulted from a 100-fold dilution of immobilized avidin with inert gel (see under Materials and Methods). Thus, gels having as much as a 100 -fold higher capacity to bind biotin can be obtained simply by diluting the immobilized avidin less.

The initial slopes of 0.93 and $0.85 \mathrm{ob}-$ served for the plots of the amount of Binsulin and BPE-insulin bound versus the amount of insulin derivative added (Fig. 1) indicate that essentially all of the derivatized insulin was competent to bind to the avidin Sepharose. In the presence of excess avidin Sepharose, binding of biotinoylated insulin proceeded at a reasonable rate. For example, $0.17 \mathrm{nmol}$ of BPEinsulin bound to $0.1 \mathrm{ml}$ of avidin Sepharose (containing $0.89 \mathrm{nmol}$ of sites for BPE-insulin) with a half-time of $8 \mathrm{~min}$. This halftime for binding could be decreased by using gels which contained higher concentrations of immobilized avidin. As the amount of biotinoylated insulin approached the capacity of the avidin Sepharose, the time required to ensure complete reaction (e.g., in the titrations depicted in Fig. 1) increased from 1 to 4 $h$. The decreased rate of binding with increased degree of saturation may well reflect the existence of a population of sterically hindered biotin binding sites which reacts more slowly with biotinoylated insulin.

Previous studies from this laboratory $(12,13)$ demonstrated that a phenyl ester linkage such as the one in BPE-insulin is readily cleaved at $25^{\circ} \mathrm{C}$ by treatment with $1 \mathrm{M}$ hydroxylamine at $\mathrm{pH}$ 7.0. Figure 1 illustrates the greater than $85 \%$ release of BPE-insulin from avidin Sepharose that we obtained upon treatment of the bound BPE-insulin with $1 \mathrm{M}$ hydroxylamine $(\mathrm{pH}$ 7.0) for $40 \mathrm{~min}$ at room temperature. However, well over $90 \%$ of the releasable BPEinsulin was released within $20 \mathrm{~min}$. The failure to observe quantitative release of the BPE-insulin from the avidin Sepharose appears to be due to nonspecific interactions between the BPE-insulin and the Sepharose. Thus, the inert Sepharose derivative that was used to dilute the immobilized avidin (see under Materials and Methods) exhibited a binding capacity (after incubation of $0.1 \mathrm{ml}$ gel with 2.7 nmol BPE-insulin) which was $1.2 \mathrm{nmol} / \mathrm{ml}$ gel. Most of this nonspecifically bound insulin $(0.9 \mathrm{nmol} / \mathrm{ml}$ gel $)$ was not released by treatment with hydroxylamine. This amount of nonreleasable BPE-insulin accounts for most of the nonreleasable BPEinsulin $(1.1 \mathrm{nmol} / \mathrm{ml}$ gel) which was observed when $0.1 \mathrm{ml}$ avidin Sepharose was 
incubated with $2.7 \mathrm{nmol}$ of BPE-insulin and then treated with hydroxylamine (Fig. 1). It should be noted that the nonspecific binding of proteins to the inert gel diluent can be minimized by the use of smaller volumes of gels which contain a higher fraction of the immobilized avidin.

Several control experiments were performed to verify that binding of BPE-insulin to the avidin Sepharose was dependent on the biotin:avidin interaction and that the subsequent release of bound insulin from the gel was due to hydroxylamine-mediated cleavage of the phenyl ester-containing connector arm. Little binding ( $<5 \%$ of that expected for BPEinsulin) was observed when avidin Sepharose was incubated with excess $\left[{ }^{125} \mathrm{I}\right]-$ insulin which had not been treated with BPE. Avidin Sepharose that had been treated with hydroxylamine and then washed with buffer was indistinguishable from untreated avidin Sepharose with respect to its ability to bind biotin or BPEinsulin. Incubation of the avidin Sepharose with biotin prior to treatment of the gel with BPE-insulin resulted in binding which was at the level seen for the nonspecific binding of BPE-insulin to the inert Sepharose diluent. Similarly, when avidin Sepharose was saturated with BPE-insulin and then treated with hydroxylamine to release the bound insulin from the gel, the resulting avidin Sepharose had a capacity for additional BPE-insulin which was less than $10 \%$ of that observed for avidin Sepharose which had not been preincubated with BPE-insulin and hydroxylamine. These results suggest that the pretreatment of the avidin Sepharose with BPE-insulin and hydroxylamine, like the pretreatment of avidin Sepharose with free biotin, saturated the insulin-accessible biotin binding sites on the immobilized avidin, and thereby prevented subsequent binding of BPE-insulin.

In the absence of added hydroxylamine, bound BPE-insulin was not released from avidin Sepharose by extensive washing with neutral buffers at either low or high concentrations of salt. The view that the release of insulin from avidin-bound BPEinsulin is dependent upon hydroxylamine- mediated cleavage of the phenyl ester linkage was further substantiated by studies with B-insulin wherein the biotin label is connected to insulin via a connector arm which should not be cleaved by the hydroxylamine treatment. As shown in Fig. 1 , avidin Sepharose bound $B$-insulin and BPE-insulin similarly. However, less than $2 \%$ of the bound $\mathrm{B}$-insulin was released from the avidin Sepharose by the hydroxylamine treatment.

The possibility that the hydroxylamine treatment described in this work could result in chemical modification of protein should be considered. Bornstein and Balbian (2) have shown that treatment of reduced carboxymethylated ribonuclease for $2 \mathrm{~h}$ at $45^{\circ} \mathrm{C}$ with $2 \mathrm{M}$ hydroxylamine in 0.2 $\mathrm{M} \mathrm{K}_{2} \mathrm{CO}_{3}$ at $\mathrm{pH} 9$ resulted only in cleavage at an Asn-Gly bond and 5-10\% cleavage at an Asn-Leu bond. It should be noted that this hydroxylamine-mediated cleavage requires hydroxide ion-catalyzed attack of the nitrogen atom of the amide backbone on the $\beta$-carboxamido group of the Asn to displace ammonia and form a cyclic imide. It is this imide intermediate which is then cleaved upon attack by the nucleophile hydroxylamine (1). Hydroxide ion-catalyzed formation of the imide intermediate should be several hundred times slower at $\mathrm{pH} 7.0,25^{\circ} \mathrm{C}$ than at $\mathrm{pH}$ $9.0,45^{\circ} \mathrm{C}$. Thus, hydroxylamine-mediated peptide bond cleavage should not be significant under the conditions used to cleave the phenyl ester linkage. Naturally, one cannot a priori exclude the possibility that some proteins might contain a bond which is reactive toward hydroxylamine. Should this become a concern, however, one could use a weaker nucleophile such as imidazole to cleave the phenyl ester linkage (12).

The selective binding of BPE-insulin to avidin and its subseqent release suggests that BPE will enable us to exploit fully the high affinity of avidin for biotin in the design of protocols for selective retrieval of biotinoylated compounds from cells and physiological fluids. In the case of insulin, it is likely that some of the BPE-insulin derivatives will be useful for the isolation and characterization of the insulin receptor, since biotinoylated insulin derivatives 
are competent to bind the insulin receptor of rat epididymal fat cells and induce insulin-like effects on metabolism ((9), and unpublished observations of this laboratory). A possible limitation of the use of the biotin label (as well as any other probe) is that the label itself might modify the physiological properties of the polypeptide so as to produce "artifactual" behavior. Determination of the behavior of several different polypeptide derivatives should minimize this problem, however.

\section{REFERENCES}

1. BORNSTEIN, P. (1970) Biochemistry 9, 2408-2421.

2. BoRnstein, P., AND BaLbIaN, G. (1970) J. Biol Chem. 245, 4854-4856.

3. Cuatrecasas, P., AND Parikh, I. (1972) Biochemistry 11, 2291-2299.
4. FreYchet, P., Roth, J., AND NEville, D. M., JR. (1971) Biochem. Biophys. Res. Commun. 43, 400-408.

5. GREEN, N. M. (1965) Biochem. J. 94, 23c-24c.

6. GREEN, N. M. (1966) Biochem. J. 101, 774-780.

7. GREEN, N. M. (1975) Advan. Protein Chem. 29, 85133.

8. HofmanN, K., Wood, S. W., Brinton, C. C., Montibeller, J. A., AND FinN, F. M. (1980) Proc. Nat. Acad Sci. USA 77, 4666-4668.

9. May, J. M., Williams, R. H., and De HaEN, C. (1978) J. Biol Chem. 253, 686-690.

10. ORR, G. A. (1981) J. Biol Chem. 256, 761-766.

11. SCHWYZER, R., ISELIN, B. M., AND FEURER, M. (1962) Chem. Abst. 56, 4864; Ger. Pat. 1,085,881, July 28,1960 (Cl. 12 p).

12. Singh, P., LEWIS, S. D., AND ShAFER, J. A. (1979) Arch. Biochem. Biophys. 193, 284-293.

13. SiNGH, P., LEWIS, S. D., AND SHAFER, J. A. (1980) Arch. Biochem. Biophys. 203, 774-779. 